ON THE QUANTA EXPLANATION OF VISION 


\title{
ON THE QUANTA \\ EXPLANATION OF VISION
}

\author{
PROEFSCHRIFT
}

TER VERKRIJGING VAN DE GRAAD VAN DOCTOR IN DE WIS- EN NATUURKUNDE AAN DE RIJKS-UNIVERSITEIT TE UTRECHT, OP GEZAG VAN DE RECTOR MAGNIFICUS DR. H. WAGENVOORT, HOOGLERAAR IN DE FACULTEIT DER LETTEREN EN WIJSBEGEERTE, VOLGENS BESLUIT VAN DE SENAAT DER UNIVERSITEIT IN HET OPENBAAR TE VERDEDIGEN OP MAANDAG 7 MAART 1949, DES NAMIDDAGS TE 4 UUR

DOOR

MAARTEN ANNE BOUMAN

GEBOREN TE UTRECHT

Springer-Science+Business Media, B.V.

1949 
AAN MIJN OUDERS

AAN TREES 


\section{VOORWOORD}

Bij de voltooiïng van dit proefschrift betuig ik gaarne mijn dank aan allen, die tot mijn wetenschappelijke vorming hebben biigedragen.

Allereerst, U Hooggeleerde Milatz, Hooggeachte Promotor, ben ik dankbaar voor de wijze, waarop $U$ mij in staat gesteld hebt de onderwerpen, die mijn belangstelling hadden te bewerken. Zeer in het bijzonder ben ik $U$ erkentelijk voor $U w$ daadwerkelijke steun mij geboden in moeilijke omstandigheden voortvloeiend uit de oorlogstoestand.

U, Hooggeleerde We ve, dank ik voor de belangstelling, die $\mathrm{U}$ steeds voor mijn werk hebt getoond. Dat ik een gedeelte van de experimenten voor dit proefschrift als medewerker van de Organisatie voor Zuiver Wetenschappelijk Onderzoek verrichtte, was mede aan Uw medewerking te danken.

Zeergeleerde $\mathrm{Fischer}$, de gedachtenwisselingen, die ik met $\mathrm{U}$ heb mogen voeren, hebben veel bijgedragen voor het verkrijgen van dieper inzicht in zintuig-physiologische problemen. Uw hulp voor het verschijnen van dit manuscript heb ik op hoge prijs gesteld.

Beste van der Velden en ten Doesschate. De onderlinge discussies, wederzijdse hulp en samenwerking waren voor mij zeer waardevol.

Tenslotte dank ik alle medewerkers van het Physisch Laboratorium voor de vriendschap en medewerking. 


\title{
ON THE QUANTA EXPLANATION OF VISION
}

BY

\author{
M. A. BOUMAN
}

11 V-'48

Survey of contents.

Page

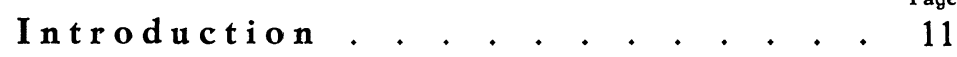

I. The two-quanta explanation

1. The experiments of van der Velden and the theoretical foundation of the two-quanta explanation

2. Theoretical and experimental observations on the two-quanta explanation . . . . . . . . 22

II. The deviations from the two-quanta explanation for threshold-values when the flash-time and the visualangle of the test spot are large

1. Our confirmation of the two quanta theory when $t<\tau$ and $d<D$. . . + . . . . . . . 29

2. The discussion of the deviations . . . . . . 31

III. The two-quanta hypothesis as a general explanation for the behaviour of threshold-values for the several receptors of the human eye

1. The experimental arrangement . . . . . . 38

2. The peripheral threshold-measurements . . . . 39

3. The central-foveal threshold-measurements . . 44

4. The mutual dependence of the receptors of different kinds in the retina . . . . . . . . . 49

IV. Some properties of the nervous system of the visual sense

1. The nerve-elements . . . . . . . . . 54

2. Some properties of the transmission in the nervous system 
V. The sensitivity dependence on wave-length for foveal and peripheral vision and the fundamental response curves

1. Introduction . . . . . . . . . . . . . 62

2. The peripheral sensitivity measurements . . . . 63

3. The foveal sensitivity measurements . . . . 65

VI. The quanta-explanation and the brightness-impression

1. The experiments . . . . . . . . . . . . 74

2. Discussion . . . . . . . . . . . . . , 79

$\approx$. The dependence on time. . . . . . . . 79

3. The dependence on the visual angle. . . . 80

3. Conclusion . . . . . . . . . . . . . . 81

VII. Visual Acuity . . . . . . . . . . . . . . 85

VIII. Aspects of vision . . . . . + . . . . . . . 90

IX. Summary . . . + . . . . . + . . . . . 94

Zusammenfassung . . . . . . . . . . . . 97

References . . . . . . . . . . . . 101 